\title{
Diabetes Mellitus Management during the Coronavirus disease-19 Pandemic: Literature Review
}

\author{
Dody Hendro Susilo ${ }^{1}$, Kusbaryanto Kusbaryanto ${ }^{1,2}$, Mahendro Prasetyo Kusumo ${ }^{1,2 \star}$ \\ ${ }^{1}$ Masters of Hospital Administration Postgraduate Program, Universitas Muhammadiyah Yogyakarta, Bantul, Indonesia; \\ ${ }^{2}$ Departement of Public Health, Faculty of Medicine and Health Sciences, Universitas Muhammadiyah Yogyakarta, Bantul, \\ Indonesia
}

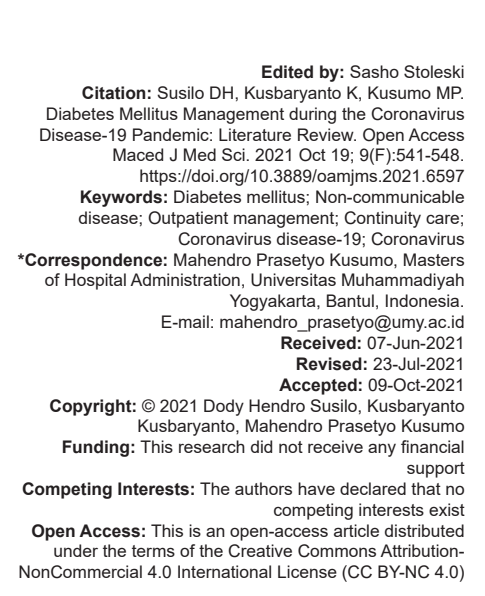

\section{Abstract}

AIM: This paper aims to analyze the development of diabetes mellitus (DM) health service management during the coronavirus disease (COVID-19) pandemic situation. DM is a disease that has an increasing prevalence from year to year and has a high morbidity rate. This is not only the case in Indonesia but also globally. The severity of both diseases (DM and COVID-19) then demands the management of comprehensive patient services so as to reduce the risk of morbidity.

METHOD: The method used in this writing is the literature review method, carried out by examining journals' articles published between 2020 and 2021.

RESULTS: The results showed that the impact of COVID-19 pandemic prevention will worsen the condition of DM sufferers where there will be the restrictions on the supply of healthy food, changes in eating habits, and access to health services due to concerns about COVID-19.

CONCLUSIONS: Hence, the conclusion is, during the COVID-19 pandemic situation, it was necessary to adjust the management of DM services to prevent complications from DM itself by utilizing health technology. The use of telehealth in diabetes service management needs to be developed as a solution to prevent and treat DM during the COVID-19 pandemic

\section{Introduction}

Diabetes mellitus (DM) is a disease commonly found in developing countries and is the leading cause of morbidity and mortality [1]. Indonesia is one of the countries with the most DM in Southeast Asia with a prevalence of $11.3 \%$ and ranks $3^{\text {rd }}$ among other countries in Southeast Asia [2]. This shows that DM requires good management so as to prevent further morbidity and mortality.

The prevalence of DM is increasing rapidly and is dangerous because the disease is a common chronic disease that affects many people. DM has lifestylerelated risk factors that require lifelong management and can lead to life-threatening complications if not properly controlled [3]. Complications of both diseases cause social and economic burdens. This is further compounded because DM is a risk factor for cardiovascular disease (CVD), which is responsible for 17 million (31\%) deaths globally and are more common in developing countries [4]. Factors that exacerbate morbidity and mortality for people with diabetes are metabolic risk (i.e., high body mass index) and behavioral factors (i.e., poor diet, smoking, and low physical activity) [5].

DM is a lifelong disease, of course it requires ongoing care, as a result it will result in a high economic burden. In Indonesia, the economic burden of DM was $\$ 0.81$ billion in 2014 and increased $56 \%$ to $\$ 1.27$ billion in 2020 [6]. This economic burden will continue to increase considering the number of people with DM will continue to increase every year and complications due to DM itself. Therefore, the health services available in various countries must be able to provide comprehensive services so that morbidity due to DM can be reduced.

$\mathrm{DM}$ is a type of non-communicable disease (NCD) but causes a large number of deaths. NCD are a global public health problem and have been designated by the World Health Organization (WHO) to be a priority because NCS mortality is so high that it is referred to as an "invisible epidemic." NCD is the leading cause of death both globally and in most developing countries. The number of deaths caused by NCD is at $80 \%$ [1].

Due to its severity, the management of patients with NCD needs to be done well and requires good support from hospital management. Complications 
then arise because the management of NCD requires the regular availability of drugs, laboratory facilities, good data collection tools, trained health workers and educated and empowered patients in addition to health services tailored to the social and life characteristics of the individual [7]. Therefore, the health services available in various countries must be able to provide comprehensive services so that the morbidity due to NCD, especially DM can be reduced.

The 2019 coronavirus disease (COVID-19) outbreak by the new coronavirus severe acute respiratory syndrome coronavirus 2 (SARS-CoV2) is a leading health problem worldwide due to its infectious nature, high morbidity and mortality rates. The current pandemic has also brought a new situation related to cardiovascular complications and comorbidities that mainly lead to hypertension (HT) and DM [8]. The incidence of HT, cardiocerebrovascular disease (CVD), and DM has been found to be approximately two, three, and twofold higher, respectively, in intensive care unit (ICU) severe cases than in non-ICU [9].

Prevention, early detection, and continuous patient monitoring are essential primary care characteristics for patients with DM. During the COVID-19 pandemic, patients and health-care facilities have cancelled or delayed many outpatients visits due to the risk of infection [8]. The risk of morbidity and mortality will accumulate with reduced health monitoring of NCD thus long-term consequences result in failure to detect, prevent, and treat acute conditions, such as hyperglycemia crisis in people with DM and HT crisis [10]. To mitigate these long-term consequences, health-care providers should take steps to ensure safe primary care services for DM sufferers during the COVID-19 pandemic era. The aim of this literature review is to understanding DM management in hospital during COVID-19 pandemic.

\section{Research Method}

The study with the literature review method aim is to help researchers better understand the background of the research that is the subject of the topic sought, which is related to services for patients with DM during the COVID-19 pandemic. Data collection using databases including PUBMED and ScienceDirect in the period 2020 2021. The study was conducted in May 2021. The literature review was carried out by reviewing journals by entering the keywords "DM," "NCD's," "outpatient management," "continuity care" "COVID-19," and "coronavirus."

The article selection method was also used in this study. Based on the keywords entered, a selection of various research results that emerged was adjusted to the research objective, namely knowing the management of DM services during the COVID-19 pandemic. After that the organization of the articles obtained by using bibliographic software such as Mendeley. The researcher will record and report the details of the number of references obtained the number of references that will be included and excluded.

The data analysis carried out by researchers in this literature review used the critical assessment method, with the process of analyzing journals used as a theoretical basis for the differences, similarities and deficiencies of the selected journals. Journals were reviewed to select the appropriate ones to answer the research questions. This is done from one topic to another so that the researcher then synthesizes and translates the results of the literature review into a systematic discussion. This will then produce an article on the management of DM during the COVID-19 pandemic.

\section{Research Results and Discussion}

\section{Research result}

Based on search results on Google Scholar, Pub Med, ScienceDirect with the keywords "DM," "NCD's," "outpatient management," "continuity care," "COVID-19," and "coronavirus;" researchers found 1255 journals' articles that match these keywords published from the beginning of 2020 to May 2021 (Figure 1).

When we are checking for duplications through Mendeley, we found 111 articles that have duplications in content, so we eliminated the 111 journals' articles that have the same content. From this step, we now have the total of 1128 journals' articles from many journals found according to the search keywords. After that we do the first screening of the journals' articles that have the full-text; and then 861 journals' articles were excluded in this step. After did this step, we just have only 267 journals' articles left.

After that, a feasibility assessment of 267 full text journals' articles was carried out, journals' articles that did not meet the inclusion criteria were excluded as many as 241 journals' articles. Hence, at last, only 16 full text journals' articles were reviewed and used for this research.

\section{Discussion}

\section{Management of patients with DM during the COVID-19 pandemic in Indonesia}

On January 30, 2020, the WHO declared the COVID-19 outbreak a public health emergency of international concern and a global disaster. On March 11, 2020, the outbreak escalated into a pandemic and spread throughout the world. Globally, as of May 24, 2021, 166,860,081 confirmed cases of COVID-19 


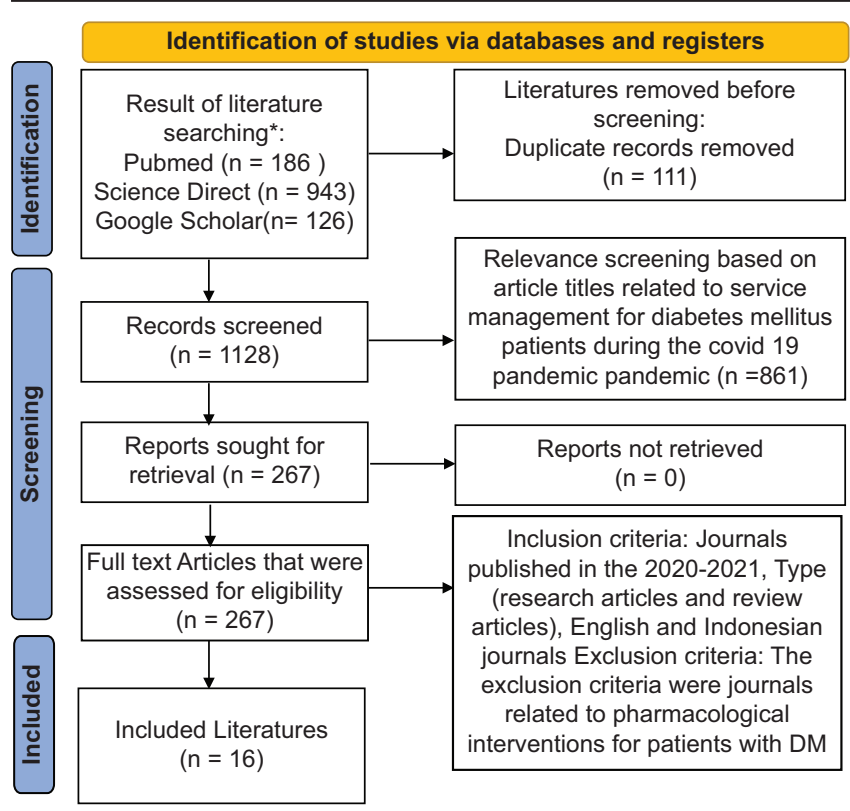

Figure 1: Identification of studies via databases and registers

have been reported in 222 countries with 3,459,966 deaths, including Indonesia. The coronavirus pandemic caused by SARS-CoV-2 (the disease is known as COVID-19). Data in Indonesia at this time also show an increasing fluctuating trend which is overshadowed by the possibility of a second wave of the pandemic such other countries [11].

Based on data from the COVID-19 Prevention Task Force (Task Force) in Indonesia, in May 2021 1,781,127 confirmed cases were found with 49,455 deaths. The age group at risk of experiencing death due to COVID-19 is the age group $>60$ years $(49.4 \%)$ and the age group $46-59$ years (35.5\%) [12]. The highest risk factors are people with a history of chronic HT, DM, chronic lung disease, and CVD who will experience complications or worsen the condition, even die during the COVID-19 pandemic [13].

A history of chronic disease (as a comorbid) is a case of many COVID-19 patients, one of which is a COVID-19 patient with DM. The condition of comorbidities shows that the percentage of positive COVID-19 patients with DM ranks second with $36.6 \%$ of cases, $26.4 \%$ recovery rate, and $9.5 \%$ death. Diabetes is the second comorbid disease at risk of contracting COVID-19, where the cure rate is still low compared to HT (26.4\% vs. $40.3 \%)$ [12].

Diabetes was the second most common NCD in individuals requiring treatment for COVID-19 (prevalence $=10.0 \%, 95 \%$ confidence interval [Cl] $8.0-12.0 \%)$ and was highly correlated with disease severity (odds ratio [OR] $2.61,95 \% \mathrm{Cl} 1.93$ 3.52) [14]. In addition, recent studies have shown that COVID-19 patients with diabetes require more medical intervention, and have a higher mortality rate $(7.8 \%)$ versus $2.7 \%$, (adjusted hazard ratio $[H R]=1.49$ ) and multiple organ injuries than those without diabetes [15].
Patients with DM have a higher overall risk of infection that results from various disorders of innate immunity.Peoplewithdiabeteshaveimpairedphagocytosis by neutrophils, macrophages and monocytes, impaired neutrophil chemotaxis and bactericidal activity, and impaired innate cell-mediated immunity. As overall, CVDrelated deaths continue to decline among people with diabetes [15], [16].

There are two mechanisms that play a role in COVID-19 infection. First, the SARS-CoV-2 virus will enter the endocrine tract that plays a role in the regulation of blood pressure, metabolism, and inflammation. COVID-19 infection reduces the role of Angiotensin Converting Enzyme-2 (ACE-2) which causes cell damage, hyperinflammation, and respiratory failure [17]. Hyperglycemia can downregulate ACE-2 which has the potential to damage the function of pancreatic $\beta$ cells causing insulin deficiency so that cells are susceptible to inflammatory effects [18].

The second potential mechanism that explains the relationship between COVID-19 and diabetes involves the enzyme dipeptidyl peptidase-4 (DPP-4) as a functional receptor for coronavirus. Antibodies directed against DPP-4 can inhibit coronavirus infection in primary cells. DPP-4 is a type II trans-membrane glycoprotein that plays a role in glucose and insulin metabolism, but can increase inflammation in type 2 diabetes [15].

The impact of distancing, quarantine, and lockdowns on lifestyle may worsen glucose control. First, the lockdown and social distancing intended for community detention will limit the physical activity of patients with DM. Second, restrictions on food supply during the lockdown will force people with diabetes to change their eating habits that were previously associated with good glycemic control. Third, the procurement of antidiabetic drugs and glucose strips will be difficult in the midst of the ongoing restrictions. Finally, people with DM will not be able to visit their doctor for routine clinical follow-up; therefore, adjustment of anti-diabetic drugs will not be possible [19].

Many patients with DM have concerns about going to the hospital during the pandemic, leading to delayed treatment adjustments and inadequate health education. In addition, during a pandemic, limited exercise, irregular diets, and poor patient selfmanagement skills make blood glucose management more difficult [16]. Poor glucose control will result in increased morbidity and mortality due to COVID-19 (Figure 1).

\section{Management of DM services in Indonesia}

Indonesia is the $7^{\text {th }}$ country out of ten countries with the highest number of DM sufferers, which is 10.7 million people, which is also the $1^{\text {st }}$ most sufferers in the region of Southeast Asia. This is a challenge in the 
prevention and control of DM in Indonesia so that healthy individuals remain healthy in the midst of the COVID19 pandemic. Before the pandemic, prevention and control efforts were through education, early detection of NCD risk factors and standardized governance. The Government through Government Regulation number 2 of 2018, Regulation of the Minister of Home Affairs number 100 of 2018 and Minister of Health Regulation No. 4 of 2019 have determined that efforts to control $\mathrm{DM}$, is one of the minimum services that must be done by the local government. Each person with DM will receive standardized services at least once a month which includes measurement of blood glucose levels, education, and pharmacological therapy as well as referrals if necessary [13]. With this guarantee, it is hoped that all people with DM can be controlled and receive good management in order to avoid complications and premature death and can reduce the cost burden due to DM and its complications [2].

In response to the COVID-19 pandemic, the ministry of health issued a Circular of the Director General of P2P Number: HK.01.07///3402/2020 concerning Handling of People with Risk Factors and Persons with NCD During the COVID-19 Pandemic which contains preventive measures as following (Table 1) [20].

Table 1: Handling of People with Risk Factors and Persons with NCD During the COVID-19 Pandemic which contains preventive measures as following

\begin{tabular}{|c|c|c|}
\hline Prevention & Promotive & Treatment \\
\hline $\begin{array}{l}\text { 1. Stay at home, apply } \\
\text { social distancing } \\
\text { protocols, wash their } \\
\text { hands frequently and } \\
\text { wear masks if they need } \\
\text { to leave the house } \\
\text { 2. apply healthy lifestyle } \\
\text { behaviors, consume } \\
\text { healthy foods and not } \\
\text { excessive sugar, salt, fat, } \\
\text { try to do physical activity } \\
\text { for at least } 30 \text { minutes at } \\
\text { home and stop smoking }\end{array}$ & $\begin{array}{l}\text { 1. Check blood glucose } \\
\text { regularly at home or watch } \\
\text { for signs of increased } \\
\text { blood glucose such as } \\
\text { frequent urination at night, } \\
\text { frequent thirst, headache, } \\
\text { fatigue, and lethargy. } \\
\text { 2. Keep the contact number } \\
\text { of the doctor/health care } \\
\text { facility and can contact } \\
\text { digital health services } \\
\text { (SehatPedia, Halodoc, } \\
\text { Alodokter, KlikDokter, } \\
\text { ProSehat and others) }\end{array}$ & $\begin{array}{l}\text { 1. Take medicines regularly } \\
\text { according to the doctor's } \\
\text { advice } \\
\text { 2. That medicines for } \\
\text { DM sufferers of JKN } \\
\text { participants and } \\
\text { Participants who are } \\
\text { referred back during the } \\
\text { COVID } 19 \text { pandemic can } \\
\text { be obtained for } 2 \text { months } \\
\text { 3. Immediately go to a } \\
\text { health-care facility if } \\
\text { you have fever, cough, } \\
\text { shortness of breath, } \\
\text { hoarseness, and diarrhea. }\end{array}$ \\
\hline
\end{tabular}

The Indonesian Endocrinology Association (PERKENI) also provides guidance in the form of official statements and recommendations for the treatment of DM in the era of the COVID-19 pandemic number 239/PB. Indonesian Endocrinologist Association which contains recommendations for patients with DM in preventing COVID-19 [13], if infected with Covid-19 and for health care providers. The recommendations are in line with the recommendations of the Ministry of Health, except in the emphasis on health service providers to optimize the means of communication and remote consultation such as email, WhatsApp (WA), video call (VC), and telephone as a means of consulting patients to get medical advice and further treatment from doctors. We recommend doctors to facilitate patients to communicate regarding the problem of using antidiabetes drugs, insulin titration, hypoglycemia, and hyperglycemia especially in diabetes with uncontrolled glucose [13].
The implementation of service adjustments for DM sufferers still faces challenges, DM sufferers in Indonesia still experience difficulties in managing diabetes by $69.8 \%$ of DM sufferers in Indonesia. These difficulties included attending a diabetes consultation at $30.1 \%$, access to diabetes treatment $12.4 \%$, checking blood glucose levels at $9.5 \%$, controlling diet $23.8 \%$, and regular exercise $36.5 \%$. Those who had difficulty managing diabetes during the COVID-19 pandemic were 1.4 times more likely to have diabetes complications (PR: 1.41, Cl 95\%: 1.09-1.83) compared to those that do not. DM complications during the pandemic were in the form of hypoglycemia incidence of $12.90 \%$, diabetic foot ulcer $7.38 \%$, and hospital admission $6.76 \%$. For this reason, rapid and sustainable changes in the health sector are needed to reduce the impact of the COVID-19 pandemic on public health, especially chronic diseases in Indonesia [21].

\section{DM service management abroad}

\section{Diabetes self-management education during pandemic Covid-19}

Diabetes self-management education refers to a continuous process to facilitate the knowledge, skills, and abilities needed to successfully manage DM by DM sufferers themselves. It is an essential element of care for all people with diabetes and has been shown to increase patient success in managing DM [22], [23]. The American Association of Diabetes Educators has described seven patient self-care behaviors as reliable outcome measures from diabetes self-management education, namely, being active, eating healthy, taking medication, monitoring, solving problems, reducing risk, and managing healthy [22]. The use of digital diabetes education in healthcare is currently limited, and adoption is slow due to lack of budget, rigid procurement pathways, and clinical inertia. Digital interventions are low cost due to a lower level of reliance on resources for online coaching [24].

Massive Open Online Course (MOOC) can be a mechanism to provide low-cost, efficient, and accessible solutions for self-management education of diabetes that can be provided in line with social distancing measures. In addition, MOOC can provide a shared experience for many people, facilitated through discussion boards and social media that enable real support from health workers. Mackenzie et al. (2021) in his research showed that MOOC has a high retention and completion rate with $65.6 \%$ of registered users completing the course and favored diabetic mellitus because of its flexibility compared to face-to-face alternatives in the midst of this pandemic situation [24].

The educational material provided can be structured, containing the meaning and need for continuous control and monitoring of DM, complications of DM and its risks, non-pharmacological and pharmacological interventions and treatment 


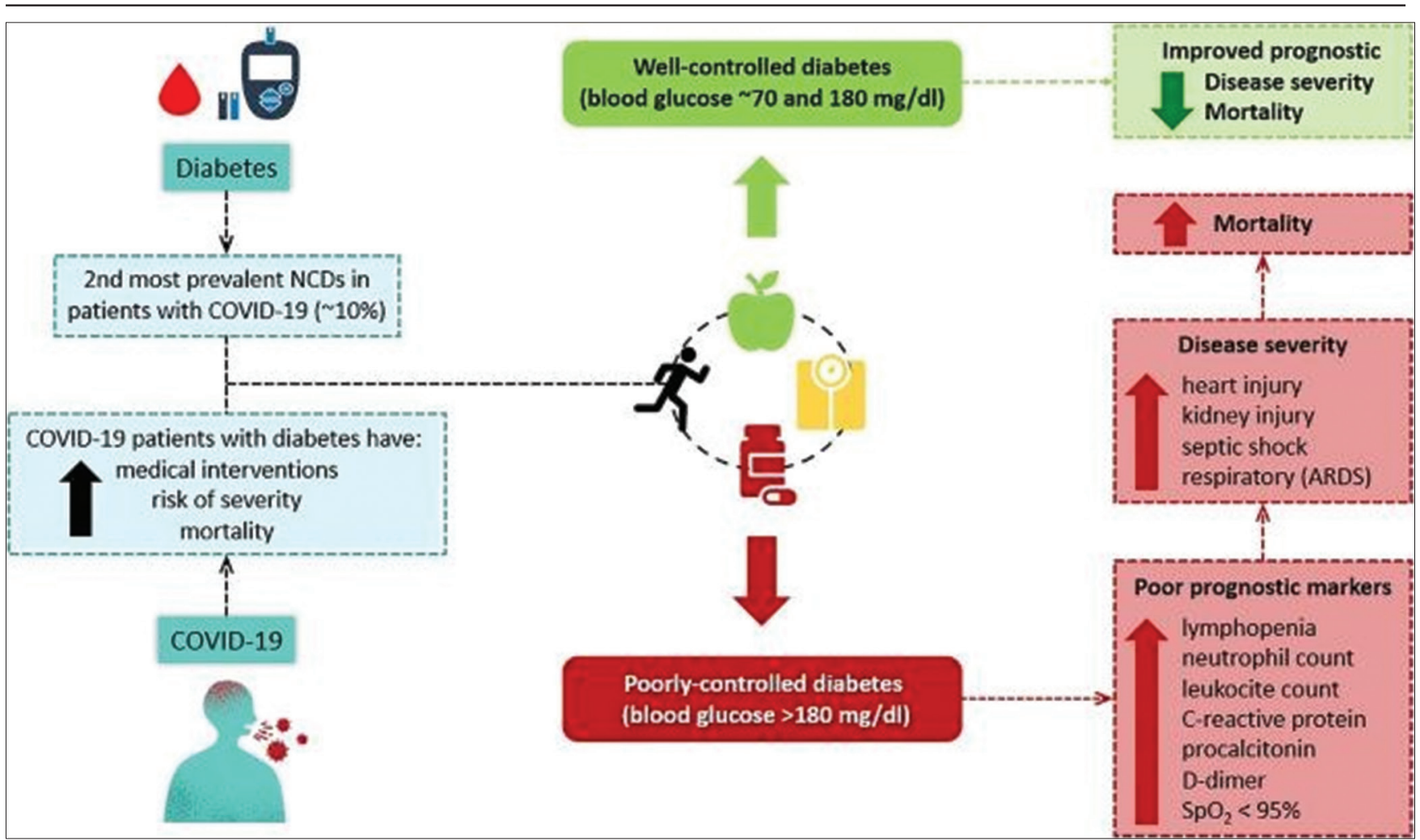

Figure 2: Relationship between diabetes and coronavirus disease 19 [20] (Marcal et al., 2020)

targets, interactions between food intake, physical activity, and oral antihyperglycemic drugs or insulin, glucose monitoring methods, understanding of blood glucose results, recognizing the symptoms and early management of hypoglycemia, the importance of regular physical exercise, the importance of foot care and how to use health-care facilities [13].

\section{Self-monitor blood glucose}

Factors that affect glycemic control in patients with DM include age, education level, availability of glucose monitoring devices, medication adherence, and frequency of self-monitoring of blood glucose. During the pandemic, diabetes self-management education should focus on medication adherence and monitoring glucose. Glycemic control may be affected during the COVID-19 epidemic. Factors that affect glycemic control in type 2 DM patients include age, education level, availability of glucose monitoring devices, medication adherence, and frequency of selfmonitoring of blood glucose [25].

There is evidence that good glycemic control can reduce the severity of COVID-19. Diabetes that was well controlled was associated with significantly lower mortality compared with individuals with diabetes who was not well controlled with adjusted $\mathrm{HR}, 0.14$; 95\% Cl, 0.03-0.60; $p=0.008$ ) [26]. Uncontrolled blood glucose predisposes people to diabetes to suffer from severe infections. To avoid this, strict glycemic control must be applied at all times. It is highly recommended to have an independent blood glucose checker so that patients with DM can check their blood glucose at home. Individuals with DM are advised to consume a proper diet and physical exercise at home. This can improve glycemic control and reduce the risk of infection [27].

For insulin patients with poor glycemic control or recurrent hypoglycemia, SMBG is recommended at least 4 times/day, namely, during fasting, before lunch, before dinner and at bedtime. Each value should be recorded within a minimum span of three days to avoid multiple punctures in a day. In addition, capillary glucose should be checked at any clinical suspicion of hypoglycemia. For patients on oral hypoglycemic agents with acceptable controls, measuring fasting and post-prandial capillary blood glucose once or twice weekly is acceptable [19].

\section{Diet and lifestyle}

The epidemic has greatly affected patients with DM, because they are isolated at home, with limited physical activity, irregular eating and sleeping patterns, and weight gain [28]. Due to the concentration of medical resources in epidemic areas and the fear of patients going to hospital, DM treatment is very limited [16]. Local culture will affect diet patterns in people with diabetes, such as in Indonesia, who tend to like sweet foods and are reluctant to refuse food offered by others [29].

Attention to adequate nutrition and protein intake is important. During the pandemic, carbohydrate consumption is expected to increase amid social 
restrictions due to limited access to the availability of fresh vegetables and fruits. Sweetened foods can be stored for a long time (even without refrigeration), consumption of such items is expected to increase during locking times [30].

Daily carbohydrate intake should be about $50-60 \%$ of total calorie intake. Pure water should be preferred over fruit juices, soda drinks, and sugar syrup which are also very expensive. The patient must remain well hydrated at all times. Fat should provide no more than $30 \%$ of the total daily caloric requirement and ideally three teaspoons of polyunsaturated oil per day (e.g., from peanut/cottonseed/olive oil) should be used in cooking. Protein intake should be $1 \mathrm{~g} / \mathrm{kg} / \mathrm{day}$, but should be less $(0.8 \mathrm{~g} / \mathrm{kg} /$ day) in people with kidney problems (diabetic nephropathy and macroalbuminuria) [30]. Telehealth said that dietary interventions targeting dietary patterns have been shown to improve diet quality, fruit and vegetable intake, and sodium intake [31].

Physical exercise or physical activity is one of the pillars in the management of DM which functions to improve insulin sensitivity and also to maintain body fitness. Physical exercise can help enter glucose into cells without the need for insulin. In addition, physical exercise is also able to lose weight in obese people with diabetes and prevent the progression rate of impaired glucose tolerance to DM. When the body moves, there will be an increase in the body's need for fuel by active muscles, as well as complex body reactions including metabolic circulation functions, hormonal release and regulation and autonomic nervous system. At rest, muscle metabolism uses very little glucose as a fuel source, while during exercise, glucose and fat will be used as the main fuel. It is hoped that by using glucose as the main fuel, blood glucose levels will decrease [32]. Physical exercise can be done by developing a Theater Performing Art (TPA)-based community empowerment. TPA-based community empowerment can create a relaxed and pleasant environment to improve blood glucose control practices in patients with DM [33].

\section{The role of technology in handling DM}

Telehealth is the use of information and communication technology, including computers and mobile devices, to access care remotely and to manage health [34]. Telehealth provides a way for patients to get ongoing care during this unprecedented time. The use of telehealth and telemedicine is not a new thing. Telehealth, part of E-Health, is a general term for clinical and non-clinical services provided remotely, while telemedicine is part of telehealth, which involves delivering clinical services to patients using electronic communications and software [35].

There are four types of telehealth platforms currently available-live video conferencing (synchronous), asynchronous meetings, remote patient monitoring, and mobile health monitoring. Telehealth had three different roles during the COVID-19 pandemic. The first is to triage or screen the patient remotely, so that clinically stable patients remain at home, reducing the rate of transmission and contraction. The second role is to provide ongoing routine care for patients with chronic diseases and those at high risk to reduce the potential exposure to the virus. The last identified role is for healthcare providers to provide uninterrupted care to their patients remotely if the healthcare provider itself contracts the virus [36].

Telehealth's potential in treating patients with DM during the COVID-19 pandemic (Figure 3).

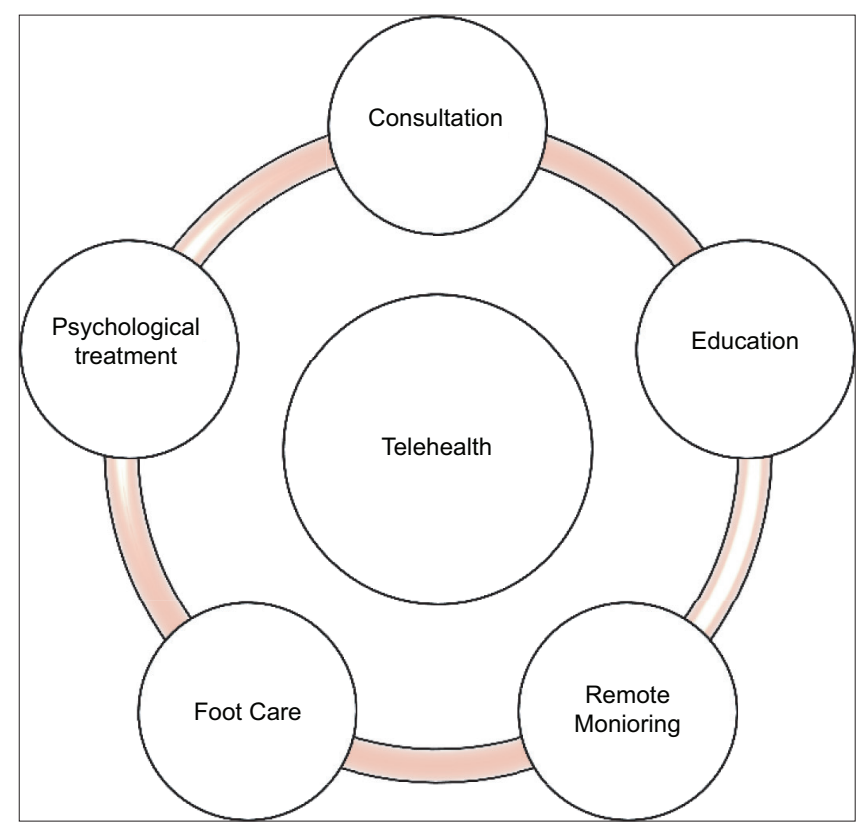

Figure 3: Telehealth's potential in treating patients with DM during the COVID-19 pandemic

\section{Consultation}

In accordance with the reduced mobilization instructions, most structured education and nonurgent routine care have been canceled or provided if necessary through remote consultation. Remote consultations may take longer than face-to-face, but the "absent" rate may be lower and patient satisfaction may be high. Prescribing, reordering, dispensing, and shipping online should be encouraged.

\section{Education}

Patient self-management is the key to a good DM outcome, which includes lifestyle management, insulin dose titration, self-care of the feet, and adherence to the treatment plan. Health-care professional support can be provided using online tools or telephone.

\section{Remote monitoring}

Glucose monitoring: Remote upload of home glucose records enables remote health care professional review and feedback to be carried out via 
the health app. Many online applications or platforms allow sharing of home activity, blood pressure, weight and other readings with health care teams, either via automatic Bluetooth connectivity or manual data entry.

\section{Foot care}

Remote solutions to support neuro-vascular assessment, diabetes ulcer risk assessment, and limited care, but simple home neuropathy tests such as the "Ipswich toe touch test" may be quite reliable when performed by relatives. Uploading digital photos from home with or without additional wound tracking apps can reduce episodes of foot ulcer complications in DM.

\section{Psychological treatment}

People with DM tend to have various levels of negative emotions, such as depression and anxiety which will naturally be exacerbated during an epidemic. Unhealthy emotions, in turn, will affect glycemic control in diabetics amid the COVID-19 pandemic [37]. A study of telecommunications in DM management also suggested that the application of electronic technology to provide a virtual environment for psychological treatment has overcome the difficulties of traditional psychological care, including face-to-face modes, the number and duration of assigned sessions, and significant personnel resources, providing adequate psychological services that beneficial for patients with DM [38]. Psychological stress can be reduced by voluntarily letting go of feelings of being locked in the house and spending quality time with loved ones instead. It is also recommended to minimize watching, reading or listening to news about COVID-19 [39].

\section{Conclusion}

The impact of COVID-19 pandemic prevention such as social distancing, reduced mobilization, and social restrictions will worsen glucose control due to reduced physical activity of DM sufferers, restrictions on the supply of healthy food and changes in eating habits and access to health services due to concerns about COVID-19. It is necessary to adjust the management of DM services to prevent complications from DM itself by utilizing health technology.

\section{Suggestion}

Telehealth-based diabetes self-management education in diabetes service management needs to be arranged between the government and health services providers, as a solution to the prevention and treatment of DM during the pandemic.

\section{References}

1. Correia JC, Lachat S, Lagger G, Chappuis F, Golay A, Beran D, et al. Interventions targeting hypertension and diabetes mellitus at community and primary healthcare level in low and middleincome countries: A scoping review. BMC Public Health. 2019;19(1):1542. http://doi.org/10.1186/s12889-019-7842-6 PMid:31752801

2. Pusdatin Kementerian Kesehatan RI. Infodatin-2020-DiabetesMelitus. Infodatin-Pusat Data dan Informasi Kementrian Kesehatan; 2020. Available from: https://pusdatin.kemkes. go.id/download.php?file=download/pusdatin/infodatin/Infodatin2020-Diabetes-Melitus.pdf. [Last accesed on 2021 May 27].

3. Bommer C, Heesemann E, Sagalova V, Manne-Goehler J, Atun R, Bärnighausen $\mathrm{T}$, et al. The global economic burden of diabetes in adults aged 20-79 years: A cost-of-illness study. Lancet Diabetes Endocrinol. 2017;5(6):423-30

PMid:28456416

4. Adinan J, Manongi R, Temu GA, Kapologwe N, Marandu A, Wajanga B, et al. Preparedness of health facilities in managing hypertension \& diabetes mellitus in Kilimanjaro, Tanzania: A cross sectional study. BMC Health Serv Res. 2019;19(1):537.

5. Lin $\mathrm{X}, \mathrm{Xu} \mathrm{Y}, \mathrm{Pan} \mathrm{X}, \mathrm{Xu} \mathrm{J}$, Ding $\mathrm{Y}$, Sun $\mathrm{X}$, et al. Global, regional, and national burden and trend of diabetes in 195 countries and territories: An analysis from 1990 to 2025. Sci Rep. 2020;10(1):14790. http://doi.org/10.1038/ s41598-020-71908-9

PMid:32901098

6. Finkelstein EA, Chay J, Bajpai S. The economic burden of selfreported and undiagnosed cardiovascular diseases and diabetes on Indonesian households. PLoS One. 2014;9(6):e99572. http:// doi.org/10.1371/journal.pone.0099572

PMid:24915510

7. Atun R, Jaffar S, Nishtar S, Knaul FM, Barreto ML, Nyirenda M, et al. Improving responsiveness of health systems to noncommunicable diseases. Lancet. 2013;381(9867):690-7. http:// doi.org/10.1016/S0140-6736(13)60063-X PMid:23410609

8. Wright A, Salazar A, Mirica M, Volk LA, Schiff GD. The invisible epidemic: Neglected chronic disease management during COVID-19. J Gen Intern Med. 2020;35(9):2816-7. http://doi. org/10.1007/s11606-020-06025-4

PMid:32666485

9. Zhu L, She ZG, Cheng X, Qin JJ, Zhang XJ, Cai J, et al. Association of blood glucose control and outcomes in patients with COVID-19 and pre-existing Type 2 diabetes. Cell Metab. 2020;31(6):1068-77.e3. http://doi.org/10.1016/j. cmet.2020.04.021

PMid:32369736

10. Scott E, Jenkins A, Fulcher GR. Challenges of Diabetes Management during the COVID-19 Pandemic How to deal with Diabetes and COVID-19-do we just Dial in? 2020. Available from: http://www.mbson [Last accessed on 2021 May 20]

11. World Health Organization. WHO Coronavirus (COVID-19) Dashboard WHO Coronavirus (COVID-19) Dashboard With Vaccination Data. Available from: https://covid19.who.int [Last accessed on 2021 Jun 17]. 
12. Peta Sebaran. Available from: https://covid19.go.id/petasebaran [Last accessed on 2021 Jun 17].

13. Suastika K. Position statement on how to manage patients with diabetes and covid-19. J ASEAN Fed Endocr Soc. 2020;35(1):49-51. http://doi.org/10.15605/jafes.035.01.03 PMid:33442169

14. Wang X, Fang X, Cai Z, Wu X, Gao X, Min J, et al. Comorbid chronic diseases and acute organ injuries are strongly correlated with disease severity and mortality among COVID-19 patients: A systemic review and meta-analysis. Research (Wash D C). 2020;2020:2402961. http://doi.org/10.34133/2020/2402961 PMid:32377638

15. Bornstein SR, Rubino F, Khunti K, Mingrone G, Hopkins D, Birkenfeld $\mathrm{AL}$, et al. Practical recommendations for the management of diabetes in patients with COVID-19. Lancet Diabetes Endocrinol. 2020;8(6):546-50. http://doi.org/10.1016/ S2213-8587(20)30152-2 PMid:32334646

16. Kang J, Chen Y, Zhao Y, Zhang C. Effect of remote management on comprehensive management of diabetes mellitus during the COVID-19 epidemic. Prim Care Diabetes. 2021;15(3):417-23.

17. Holman N, Knighton P, Kar P, O'Keefe J, Curley M, Weaver A, et al. Risk factors for COVID-19-related mortality in people with Type 1 and Type 2 diabetes in England: A population-based cohort study. Lancet Diabetes Endocrinol. 2020;8(10):823-33. http://doi.org/10.1016/S2213-8587(20)30271-0

PMid:32798471

18. Bindom SM, Lazartigues E. The sweeter side of ACE2: Physiological evidence for a role in diabetes. Mol Cell Endocrinol. 2009;302(2):193-202.

PMid: 18948167

19. Banerjee M, Chakraborty S, Pal R. Diabetes self-management amid COVID-19 pandemic. Diabetes Metab Syndr Clin Res Rev. 2020;14(4):351-4. http://doi.org/10.1016/j.dsx.2020.04.013 PMid:32311652

20. Kementerian Kesehatan, Surat Edaran Dirjen P2P Nomor: HK.01.07///3402/2020 Tentang Penanganan Orang Dengan Faktor Risiko dan Penyandang Penyakit Tidak Menular Dalam Masa Pandemi COVID-19; 2020.

21. Kshanti IA, Epriliawati M, Mokoagow MI, Nasarudin J, Magfira N. The impact of coronavirus disease 2019 pandemic on people with diabetes in Indonesia: A cross sectional national scale websurvey. medRxiv. 2020;2020:20241588.

22. Haas L, Maryniuk M, Beck J, Cox CE, Duker P, Edwards L, et al. National standards for diabetes self-management education and support. Diabetes Care. 2012;35(11):2393-401. http://doi. org/10.2337/dc12-1707 PMid:22995096

23. Kusumo MP, Prabandari YS, Dewi FST. Measuring the knowledge, attitude and practice of patients with diabetes mellitus the design and development process. 2021;2021:2110221. http://doi.org/10.1177/0272684X211022173 PMid:34148428

24. Mackenzie S, Cumming K, Garrell D, Brodie D, Wilson L, Mehar S, et al. Massive open online course for Type 2 diabetes self-management: adapting education in the COVID-19 era. BMJ Innov. 2021;7:141-7. http://dx.doi.org/10.1136/ bmjinnov-2020-000526

25. Tao J, Gao L, Liu Q, Dong K, Huang J, Peng X, et al. Factors contributing to glycemic control in diabetes mellitus patients complying with home quarantine during the coronavirus disease 2019 (COVID-19) epidemic. Diabetes Res Clin Pract.
2020;170:108514. http://doi.org/10.1016/j.diabres.2020.108514 PMid:33068663

26. Pasquel FJ, Lansang MC, Dhatariya K, Umpierrez GE. Management of diabetes and hyperglycaemia in the hospital. lancet Diabetes Endocrinol. 2021;9(3):174-88. http://doi. org/10.1016/S2213-8587(20)30381-8 PMid:33515493

27. Alisa F, Amelia W, Sastra L, Depitasari L. Online education on the implementation of physical activity in diabetic patients. LI-Dikti Ix. 2020;2:53-7.

28. Kusumo MP. Physical activity patterns in lecturers during Covid-19 pandemic: A qualitative study. JMMR. 2021;10(1):3545. https://doi.org/10.18196/jmmr.v10i1.10829

29. Kusumo MP, Hendrartini J, Sufro ZM, Dewi FS. A qualitative study to explore the perception of patients towards diet in Javanese culture. Enferm Clin. 2020;30:183-7. https://doi. org/10.1016/j.enfcli.2020.06.041

30. Gulati S, Misra A. Sugar intake, obesity, and diabetes in India. Nutrients. 2014;6(12):5955-74. http://doi.org/10.3390/ nu6125955

\section{PMid:25533007}

31. Kelly JT, Reidlinger DP, Hoffmann TC, Campbell KL. Telehealth methods to deliver dietary interventions in adults with chronic disease: A systematic review and meta-analysis 1 . Am J Clin Nutr. 2016;104(6):1693-702. http://doi.org/10.3945/ajcn.116.136333 PMid:27935523

32. Azitha M, Aprilia D, Ilhami YR. Hubungan aktivitas fisik dengan kadar glukosa darah puasa pada pasien diabetes melitus yang datang ke poli klinik penyakit dalam rumah sakit $\mathrm{m}$. djamil padang. J Kesehatan Andalas. 2018;7:893. https://doi. org/10.25077/jka.v7i3.893

33. Kusumo MP, Hendrartini J, Sufro ZM, Dewi FS. Theater performing Arts (TPA): Community empowerment to improve blood glucose control behavior in Yogyakarta. Int J Endocrinol Metab. 2020;18(4):e103106. http://doi.org/10.5812/ijem.103106 PMid:33613677

34. Andrews E, Berghofer K, Long J, Prescott A, Caboral-Stevens M Satisfaction with the use of telehealth during COVID-19: An integrative review. Int J Nurs Stud Adv. 2020;2:100008. http:// doi.org/10.1016/j.jnsa.2020.100008

PMid:33083791

35. Cranford. Telemedicine Vs telehealth: What's the Difference; 2020. Available from: https://chironhealth.com/blog/ telemedicine-vs-telehealth-whats-the-difference [Last accessed on 2021 May 24].

36. News Healthcare IT News; 2021. Available from: https:// www. healthcareitnews.com/news/telemedicine-duringcovid-19- benefits-limitations-burdens-adaptation [Last accessed on 2021 Jun 18].

37. Kusumo MP, Hendrartini J, Sufro ZM, Dewi FS. Theater performing art: A strategy to improve self-efficacy and social support in patient with Type 2 diabetes mellitus (T2DM). J Glob Pharma Technol. 2020;12(6):70-6.

38. Lanzola G, Losiouk E, Del Favero S, Facchinetti A, Galderisi A Quaglini S, et al. Remote blood glucose monitoring in mHealth scenarios: A review. Sensors (Switzerland). 2016;16(12):1983. http://doi.org/10.3390/s16121983 PMid:27886122

39. World Health Organization. Mental Health and Psychosocial Considerations During COVID-19 Outbreak. Geneva: World Health Organization; 2020. p. 1-6. 